\title{
The Bessey Microscopy Facility: a Biotechnology and Life Sciences Center at Iowa State University
}

\author{
T. M. Pepper, ${ }^{*}$ R. L. Denadel, ${ }^{*}$ C. J. Van Allen, ${ }^{*}$ and H. T. Horner**** \\ *Bessey Microscopy Facility, Iowa State University, Ames, IA 50011-1020 U.S.A. \\ **Genetics, Development and Cell Biology, Iowa State University, Ames, IA 50011-1020 U.S.A.
}

The Bessey Microscopy Facility (BMF) is one of 25 Biotechnology and Life Science Centers at Iowa State University under the umbrella of the Office of Biotechnology. The BMF provides a variety of instrumentation, technical assistance, consultation, and training to individuals and groups of researchers who want to use photomacrography, light microscopy, scanning and transmission electron microscopy, cryopreservation, cytochemistry, autoradiography, X-ray microanalysis, and image analysis. The 24-room BMF is housed in the basement of Bessey Hall and consists of specimen and specialty preparation labs, microtomy rooms, vibration-free microscope suites, a computer image suite, a dark room, offices, and a conference room.

Electron microscopy (STEM and SEM): Instrumentation includes a JEOL 1200EX scanning / transmission electron microscope with x-ray elemental and image analysis systems, and digital image capture using a Soft Imaging Systems (SIS, Inc.) Megaview III camera; and a JEOL 5800LV scanning electron microscope with x-ray elemental and image analysis systems, and a SIS, Inc. ADDA II digital image capture system.

Light microscopy (LM and Stereo): Instrumentation includes a Zeiss Axioplan II compound microscope equipped with bright-field, phase-contrast, polarizing, darkfield, fluorescence, differential interference contrast (Nomarski), and Apotome optics, and AxioCam MRC/MRM digital camera systems; stereo and dissecting microscopes, including an Olympus SZH-10 stereomicroscope with an AxioCam HRC digital camera for macro specimen imaging; a microspectrophotometer/fluorometer; a micromanipulator and microforge; a TV and image analysis system; a Bencher 35-mm recording system; and an ancillary Leitz photomicroscope, with all optics shown for the Zeiss microscope, that has an automatic film color and B/W camera and color TV monitor.

Access to BMF: In addition to the 24/7/52 open hours for trained researchers, the BMF carries out full-service work for both on- and off-campus researchers. The BMF not only provides research service for graduate students, professional and scientific staff, postdoctoral fellows, research faculty, and off-campus researchers, but it also offers three graduate-level courses in LM, SEM, TEM (5 credits each), workshops, educational tours and demonstrations to elementary through undergraduate students. The BMF support comes from the Office of Biotechnology, the Vice Provost for Research, the Liberal Arts and Sciences College, the Department of Genetics, Development and Cell Biology, and from the BMF charges made to on- and off-campus users, private companies, and government facilities. The BMF handles a large variety of projects (Table 1, Figure 1A-L) each year for 90 to 100 researchers. These projects can range from a one-time use, to a monthly use, to projects that span several years. Researchers are billed monthly for services provided by the BMF. To learn more about the BMF, and the services and instrumentation it provides, we invite you to visit its website at: www.biotech.iastate.edu/facilities/BMF/. 
Table 1. Selected projects of the many BMF Research Service Projects

\begin{tabular}{|c|c|c|c|}
\hline TEM & SEM & LM & STEREO \\
\hline $\begin{array}{c}\text { A-Immunocytochemistry } \\
\text { of virus infected cell } \\
\text { cultures-isolates from } \\
\text { fat bodies in larvae of } \\
\text { corn borer }\end{array}$ & $\begin{array}{c}\text { D- Rumen contents } \\
\text { of bovine - } \\
\text { identification of } \\
\text { various protozoa }\end{array}$ & $\begin{array}{c}\text { G-Florescence of } \\
\text { acriflavin stained } \\
\text { arabidopsis tissues } \\
\text { - cleared whole } \\
\text { mounts }\end{array}$ & $\begin{array}{c}\text { J- Internal micro- } \\
\text { structure of } \\
\text { polished agate }\end{array}$ \\
$\begin{array}{l}\text { B-Negative staining of two } \\
\text { viruses isolated from } \\
\text { mammalian serum }\end{array}$ & $\begin{array}{c}\text { E-Donut-shaped } \\
\text { active floral } \\
\text { nectary in soybean }\end{array}$ & $\begin{array}{c}\text { H- Silver enhanced } \\
\text { immunogold- } \\
\text { labeled virus in } \\
\text { aphid gut }\end{array}$ & $\begin{array}{c}\text { K-GUS-stained } \\
\text { arabidopsis } \\
\text { seedling }\end{array}$ \\
\hline $\begin{array}{l}\text { C-Identification of } \\
\text { phytoplasma infection } \\
\text { in monocots }\end{array}$ & $\begin{array}{c}\text { F-Adult human stem } \\
\text { cells growing on } \\
\text { etched polystyrene }\end{array}$ & $\begin{array}{c}\text { I- Magnetotatic } \\
\text { bacterium from } \\
\text { freshwater pond }\end{array}$ & $\begin{array}{c}\text { L- Rat ovary } \\
\text { showing follicles } \\
\text { and cysts }\end{array}$ \\
\hline
\end{tabular}

* Specific identification of specimens is not included for proprietary reasons.

Figure 1A-L. Representative images from the BMF Projects identified in Table 1.

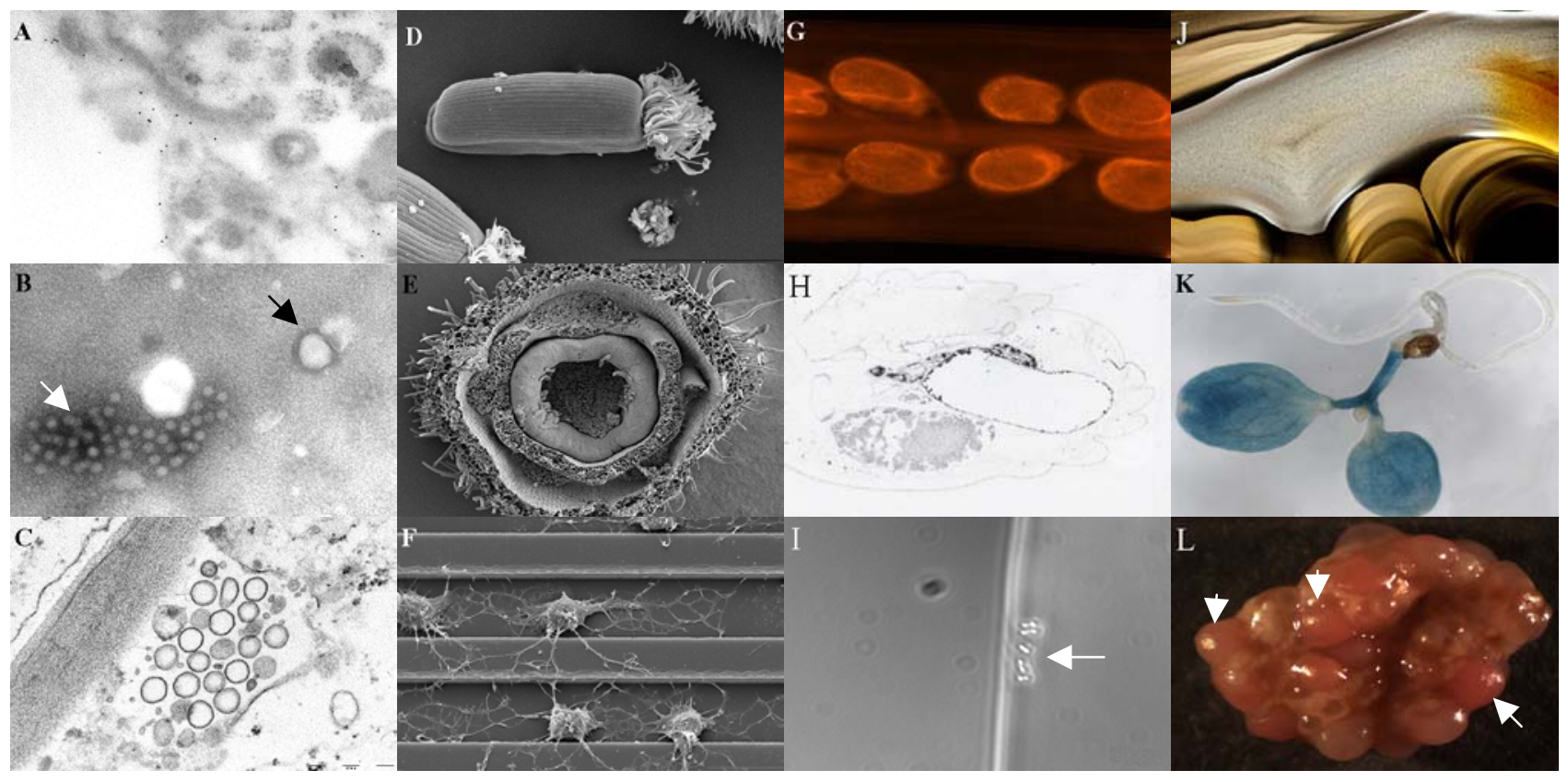

